\title{
Stress and Strain Behavior of Confined Lightweight Concrete using Sand Coated Polypropylene Coarse Aggregate
}

\author{
Heru Purnomo ${ }^{1 *}$, Heru Baskoro ${ }^{1}$, Fadhilah Muslim ${ }^{1}$ \\ ${ }^{1}$ Department of Civil and Environmental Engineering, Faculty of Engineering, Universitas Indonesia, \\ Kampus UI Depok, Depok 16424, Indonesia
}

\begin{abstract}
Plastic waste greatly contributes to environmental pollution; therefore, using plastic waste in various applications, such as in concrete, is an important waste reduction strategy which could be contributed by the construction industry. This study presents the development of a concrete stress and strain model under compression for confined concrete specimens using polypropylene plastic as a substitution for coarse aggregate. Various short-column specimens were analyzed for stress and strain characteristics, effect of steel confinement, and compressive performance. Steel confinement increased the compressive strength and ductility of the section. The parametric identification of a stress-strain model defined for normal concrete was used in the experimental results to obtain new parameter values for the confinement coefficients $\mathrm{k} 1$ that are suitable for cylindrical and square lightweight concrete sections. The stress-strain diagrams for lightweight concrete of experimental cylinder and square column specimens, compared with the stress-strain modeled by the modified coefficients, indicate a fairly close agreement.
\end{abstract}

Keywords: Compression; Confinement; Lightweight concrete; Polypropylene aggregate; Stressstrain

\section{Introduction}

Plastic wastes are almost non-degradable in the natural environment, even after a long period of exposure. The use of recycled plastic as fine and coarse aggregates in lightweight concrete has been studied by Choi et al. (2009), Frigione (2010), Al Bakri et al. (2011), and Islam et al. (2016) as part of an effort to reduce environmental pollution. The use of plastic aggregates in concrete has the additional benefit of providing a lighter weight of concrete than normal concrete containing natural aggregates. Inclusion of a plastic component as a substitution for natural coarse aggregate in concrete can therefore be a good solution to the environmental hazard posed by plastic wastes. However, a lack of information on the characteristics of lightweight concrete containing plastic aggregates is one of the main barriers hindering acceptance of this product in the construction industry. Polypropylene coarse aggregate, as shown in Figure 1, with or without sand coating, has been studied by Purnomo et al. (2017a) and Pamudji et al. (2018), who found a better bond between the coarse aggregate and hard matrix in the presence of the sand coating. Polypropylene has versatile physical characteristics and is inexpensive (Maddah, 2016; Jawaid and Khan, 2018); however, knowledge of the characteristics, strength, and stress and strain behaviors 
of lightweight concrete with plastic aggregate is still limited. In view of potential engineering problems, understanding the stress characteristics would provide insight into the structural element strength (Kurdi and Rahman, 2010; Purnomo et al., 2017b; Purnowidodo et al., 2018).

Recent studies using confined concrete constitutive models have focused more on ultra-high performance concrete (UHPC) cases (Chang et al., 2020; Li et al., 2020). By contrast, stress-strain curves for lightweight concrete using recycled plastic aggregate have been studied only on a limited scale in the laboratory. The development of stress and strain models is important for further study of the behavior of this concrete type. This behavior depends largely on the concrete compressive strength and the stress-strain relationship. The main objective of the present study is to establish a stress-strain relationship under compression of confined concrete containing recycled polypropylene (PP) plastic as coarse aggregate. The expectation is that the determined relationship could represent the overall stress-strain behavior of strength with good control over the ascending and descending branches.

\section{Methods}

\subsection{Existing Model}

From 1950 until the present, more than 10 stress-strain models have been proposed by different researchers. For example, Kent and Park (1971) proposed a stress-strain equation for both unconfined and confined concrete. Their influential confinement model was based on a square column $150 \mathrm{~mm} \times 150 \mathrm{~mm}$ and $1200 \mathrm{~mm}$ in length with four corner bars and square ties. They suggested that confinement reinforcement increased the ductility, but not the strength, of the columns. In their model, they generalized Hognestad's (1951) equation to more completely describe the post-peak stress-strain behavior. In this model, the ascending branch is represented by modifying the Hognestad second-degree parabola by replacing $0.85 \mathrm{fc}^{\prime}$ by fc' and $\varepsilon_{0}$ by 0.002 . The post-peak branch was assumed to be a straight line whose slope was defined primarily as a function of concrete strength. Saatcioglu and Razvi (1992) proposed the stress and strain model shown in Figure 2 for normal concrete, with the ascending parabola presented by the following explanation.

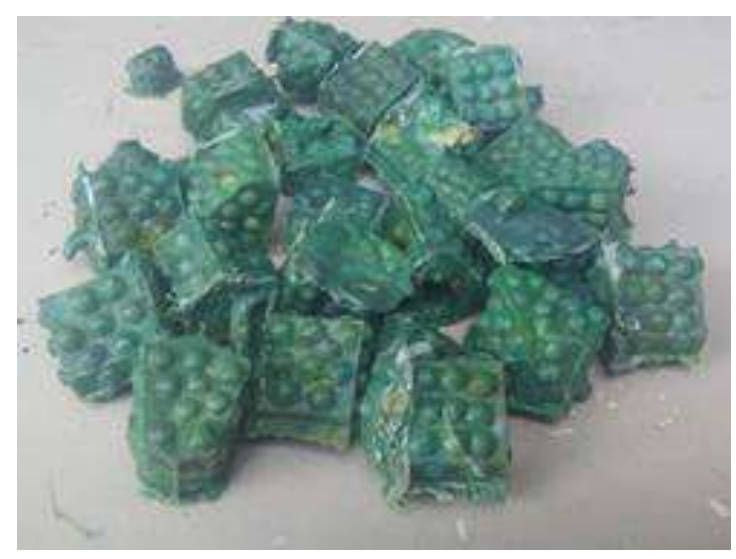

Figure 1 Uncoated plastic aggregate

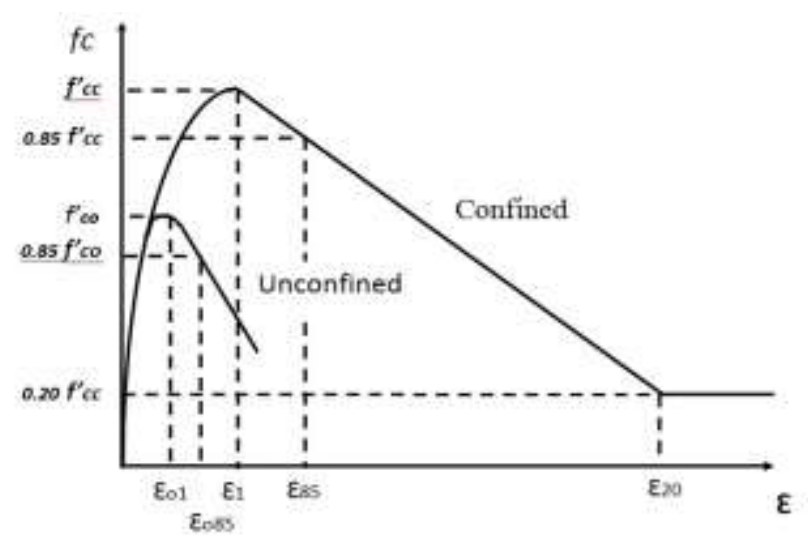

Figure 2 Stress and strain model for concrete, reproduced from Saatcioglu and Razvi (1992)

The following equations were developed based on the large number of specimens tested in the laboratory:

$$
f c=f^{\prime} c c\left[2\left(\frac{\varepsilon_{c}}{\varepsilon_{1}}\right)-\left(\frac{\varepsilon_{c}}{\varepsilon_{1}}\right)^{2}\right]^{\frac{1}{(1+2 K)}} \leq f^{\prime} c c
$$


where:

$$
\begin{gathered}
f^{\prime} c c=f^{\prime} c_{0}+k_{1} \cdot f_{l e} \\
\varepsilon_{1}=\varepsilon_{0}(1+5 K) \\
K=\frac{K_{1} \cdot f_{l e}}{f^{\prime} c 0} \\
k_{1}=6.7\left(f_{l e}\right)^{-0.17} \\
f_{l e}=k_{2} \cdot f_{l} \\
k_{2}=0.26 \sqrt{\left(\frac{b_{c}}{s}\right)}\left(\frac{b_{c}}{s_{t}}\right)\left(\frac{1}{f_{l}}\right) \leq 1.0 \\
f_{l}=\frac{\Sigma A_{s} \cdot f_{y t} \cdot \sin \alpha}{s \cdot b_{c}}
\end{gathered}
$$

\begin{tabular}{|c|c|c|c|c|}
\hline \multirow[t]{7}{*}{ where } & $\mathrm{f}_{\mathrm{c}}^{\prime}:$ & compression strength of confined concrete & $\mathrm{f}_{\mathrm{l}}:$ & lateral pressure \\
\hline & $F_{c o}^{\prime}:$ & compression strength of unconfined concrete & $b_{c}:$ & width of core specimen \\
\hline & $\varepsilon_{c}:$ & strain of plain concrete & St: & lateral spacing longitudinal reinforcement \\
\hline & $\varepsilon_{1}:$ & $\begin{array}{l}\text { strain of confined plain concrete due to } \\
\text { maximum stress }\end{array}$ & $\alpha:$ & angle between transversal rebar and $b_{c}$ \\
\hline & $\varepsilon_{01}:$ & $\begin{array}{l}\text { strain of unconfined plain concrete due to } \\
\text { maximum stress }\end{array}$ & $f_{y t}$ : & yield stress of longitudinal \\
\hline & $K, k_{1}, k_{2}:$ & coefficient of confinement & $A_{s}:$ & transversal rebar area \\
\hline & $f_{i e}:$ & lateral pressure equivalent & s : & spacing of stirrups or hoops \\
\hline
\end{tabular}

\subsection{Specimen Preparation}

The model was developed from the experimental results of compressive tests on the concrete specimens in the laboratory. All tests on the concrete specimens were carried out in the Structure and Material laboratory in the Civil Engineering Department, Universitas Indonesia, in Depok, and in the B2TKS-LUK BPPT laboratory in Serpong, south of Jakarta. One of the most important steps in the study of the behavior of lightweight concrete is to establish an appropriate analytical stress-strain relationship that captures the real observable behavior determined from real test results in the laboratory. The more stressstrain data that can be obtained from experiments, the more reliable the proposed stress and strain model will be. The stress and strain value data from experiments were used to obtain a stress and strain diagram relationship. Since the proposed developed concrete composites are new in nature, as plastic materials/PP will be used as a coarse aggregate substitute, a step-by-step procedure was adopted from previous research (Afsari, 2017; Purnomo et al., 2017a; Pamudji et al., 2018) for preparing the test samples. An overview of the previous mixed design used to produce the test specimen by previous researchers will be described in brief. The preparation of the test specimens was based on the available mix designs conducted previously by Purnomo et al. (2017a) and Pamudji et al. (2018). Three mix designs, M1, M2, and an instant concrete mix M3, were used in this experiment (Table $1)$.

Table 1 Mix design used (Purnomo et al., 2017a)

\begin{tabular}{ccccccc}
\hline Type & W/C & $\begin{array}{c}\text { Cement } \\
(\mathrm{kg})\end{array}$ & $\begin{array}{c}\text { Sands } \\
(\mathrm{kg})\end{array}$ & $\begin{array}{c}\text { Plastic } \\
\text { aggregate } \\
(\mathrm{kg})\end{array}$ & $\begin{array}{c}\text { Water } \\
(\text { liter })\end{array}$ & $\begin{array}{c}\text { Admixture } \\
(\mathrm{kg})\end{array}$ \\
\hline M1 & 0.28 & 500 & 678 & 411 & 140 & 8 \\
\hline M2 & 0.30 & 500 & 738 & 388 & 150 & 7 \\
\hline M3 (drymix) & \multicolumn{7}{c}{ Mixed instant concrete } & 140 & 7 \\
\hline
\end{tabular}


The volume proportions of each material are presented in Table 2 (Afsari, 2017). Polypropylene (PP) coarse aggregate was made from raw material consisting of pelletized PP polymer. The intended forms of coarse PP aggregate were obtained by a plastic injection process using a plastic injection machine. The results of the compression tests for the standard specimens are shown in Table 3, where 3 specimens were tested for each mixture.

Table 2 Volumetric proportion of material used in this experiment (Afsari, 2017)

\begin{tabular}{lccc}
\hline \multicolumn{1}{c}{ Material } & $\begin{array}{c}\text { Density } \\
\left(\mathrm{kg} / \mathrm{m}^{3}\right)\end{array}$ & $\begin{array}{c}\text { Volume } \\
\left(\mathrm{m}^{3}\right)\end{array}$ & $\begin{array}{c}\text { Proportion volume to } \\
\text { cement }\end{array}$ \\
\hline M1 mix design & & & \\
Cement & 3150 & $500 / 3150$ & 1 \\
Sand & 2330 & $678 / 2330$ & 1.83 \\
Plastic aggregate & 1120 & $411 / 1120$ & 2.31 \\
Water & 1000 & $140 / 1000$ & 0.88 \\
\hline M2 mix design & & & \\
\hline Cement & 3150 & $500 / 3150$ & 1.0 \\
Sand & 2330 & $738 / 2330$ & 1.99 \\
Plastic aggregate & 1120 & $388 / 1120$ & 2.17 \\
Water & 1000 & $150 / 1000$ & 0.94 \\
\hline
\end{tabular}

Table 3 Compression strength results

\begin{tabular}{cccc}
\hline Type & W/C & $\begin{array}{c}\text { Average compression } \\
\text { strength 7 days (MPa) }\end{array}$ & $\begin{array}{c}\text { Average compression } \\
\text { strength 28 days (MPa) }\end{array}$ \\
\hline M1 & 0.28 & 17.37 & 16.33 \\
M2 & 0.30 & 15.25 & 18.16 \\
M3 & 0.35 & 12.70 & 20.11 \\
\hline
\end{tabular}

One mix design (M2) in this experiment complied with the minimum requirement of compressive strength (17.2 $\mathrm{MPa})$ based on a normal cylinder specimen, as stated in Indonesian National Standard SNI 03-2847-2002. Design mixture M1 was slightly below this requirement. For this study, design mixtures M1, M2, and M3 were used for the experiment. The specimen size was determined based on the references made by previous researchers. The specimen used by Mander et al. (1988) was adopted as a reference, with approximately 33\% of its original size. The diameter of the longitudinal and confinement steel (diameter and spacing) were scaled to approximately 33\% proportionally, based on the reference specimens. The square specimen (Scott, 1980) was scaled to $1 / 3$ with proportional geometry in all axes. The slenderness ratio of both the full and reduced-scale specimens were nearly the same. At specimen failure, the theoretical nominal strength of a short axially loaded column was determined by the gross concrete area and the total crosssectional area of the longitudinal reinforcement. Therefore, the reduced specimen nominal strength was about the square of the reduced scale $(1 / 3)$ of that of the nominal strength of a full-scale specimen. A rectangular-shaped specimen has not yet been studied, but will be the subject of a future experiment. The coarse aggregate's maximum size was about $10 \mathrm{~mm}$ $\times 20 \mathrm{~mm} \times 20 \mathrm{~mm}$, and it was used for both mixtures of lightweight concrete. The coarse aggregate size was no more than $20 \%$ of the thickness of the concrete section of the reduced specimen (Neville, 2011); therefore, the compressive strength of the reduced specimen was essentially unaffected by the coarse aggregate size.

\subsection{Compression Testing of the Specimens}

A total of 20 reinforced and 12 plain specimens were compression tested in the laboratory, as shown in Figures 3 and 4, and listed in Tables 4 and 5. The various tie arrangements shown in the Figures and Tables give the variations in the lateral confining 
pressure along the member length. The length of the square column specimen was $400 \mathrm{~mm}$ and that of the cylindrical column was $500 \mathrm{~mm}$, as both types of specimens were scaled to $1 / 3$ of the original specimen length (Scott, 1980; Mander et al., 1988). The use of 20 reinforced specimens allowed us to establish the confined concrete stress-strain relationship, while the 12 plain specimens, which consisted of 6 square $(2$ sets of S5-1, S52 , and S5-3) and 6 cylindrical (2 sets of C5-1, C5-2, and C5-3) specimens, permitted us to establish the unconfined concrete stress-strain relationship. The plain cylindrical column had the same dimensions as the reinforced cylindrical column. The dimensions of the plain square column were also the same as those of the reinforced square column.
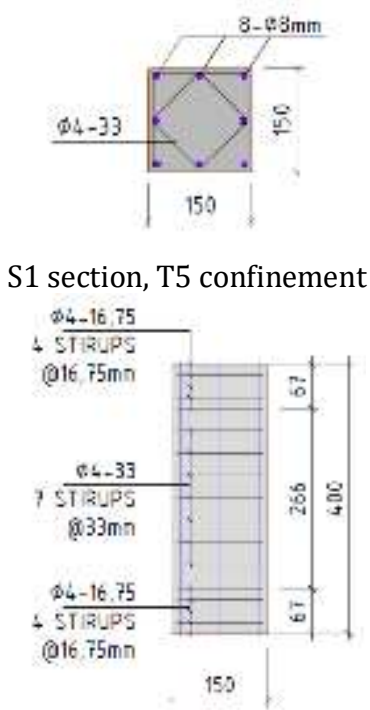

S1 Elevation
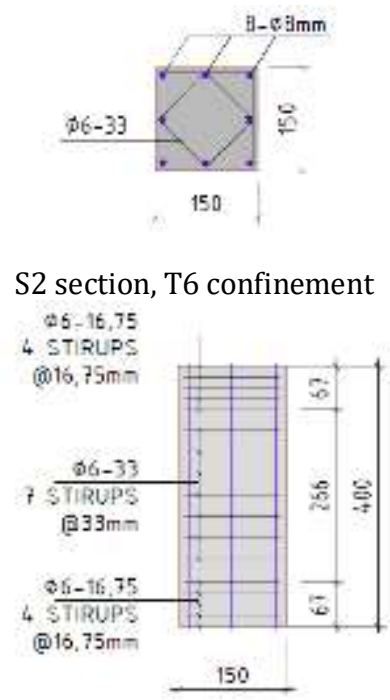

S2 Elevation

Figure 3 Square column specimens used in the experiment

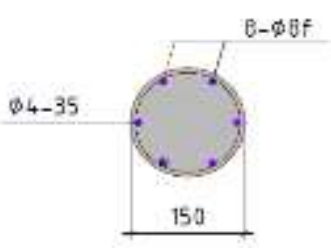

C3 section, T3 confinement

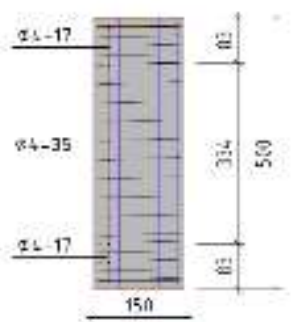

C3 Elevation

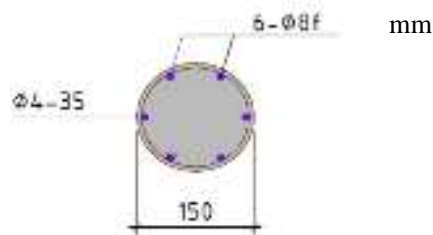

C4 section, T4 confinement

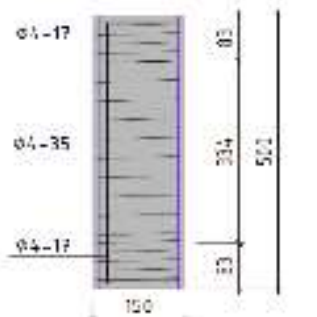

C4 Elevation

Figure 4 Cylinder column specimens used in the experiment

A JTM-2000 compression machine with a maximum capacity of $2000 \mathrm{kN}$ is available in the B2TKS Laboratory in Serpong, organized by Pusat Pengembangan Ilmu Pengetahuan dan Teknologi (PUSPIPTEK). Hinge support was provided at the bottom of the specimen to eliminate bending moment and buckling of the specimen during the compression test. Strain in the specimen was measured with a vibrating wire embedded-type GV2410 device, 
as shown in Figure 5. The vibrating wire was installed in the center of the specimen, at approximately mid-height of the column, and tied and secured by a steel wire in the rebar. During the compression test, all the visual deformations of the specimen were recorded with a high-resolution video camera. Two cameras were used during the experiment to obtain the relationship between time vs. load acting and displacement. The camera also captured the crack patterns of the specimens over time. The local strains obtained from the vibration were used to verify the measurement of the JTM machine before the peak load occurred.
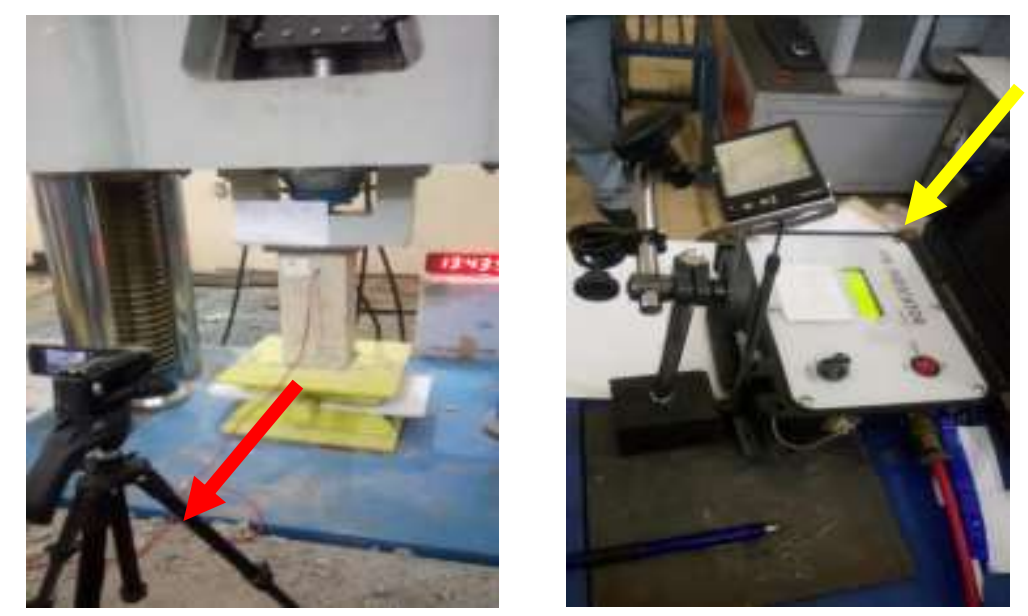

Figure 5 Specimen setting and strain recording (right) using a vibrating wire readout unit

\section{Results and Discussion}

\subsection{Comparison of Test Results}

A summary of the test results is presented in Table 5. One square specimen failed during the test due to an error in setting the machine. Data were acquired from the JTM2000 compression machine and processed in the machine's computer unit. Strain data for the confined specimens were also acquired from the vibrating wire strain gauge (VW) embedded in the specimens; those data were recorded manually from the display screen of the readout unit. The acquired data from the JTM-2000 were load versus global displacement, stress versus global displacement, time log record, force over the displacement, and video capture over the testing period. The values for force versus displacement over time (with 1 second increment) were converted to a stress vs. strain curve. The stress-strain relationship from three unconfined cylinder specimens (C5-1, C52 , and C5-3) with various concrete grades is presented in Figure 6 . The 3 curves verify the average compression strength results presented in Table 3. Figures 7 and 8 show the stressstrain curves for different types of confinement of the M1 cylinder and square specimens. The M2 specimens are not shown as they had a similar behavior but with a higher peak of stress, as indicated in Table 5. 
Table 4 Reinforcement and confinement of the specimens

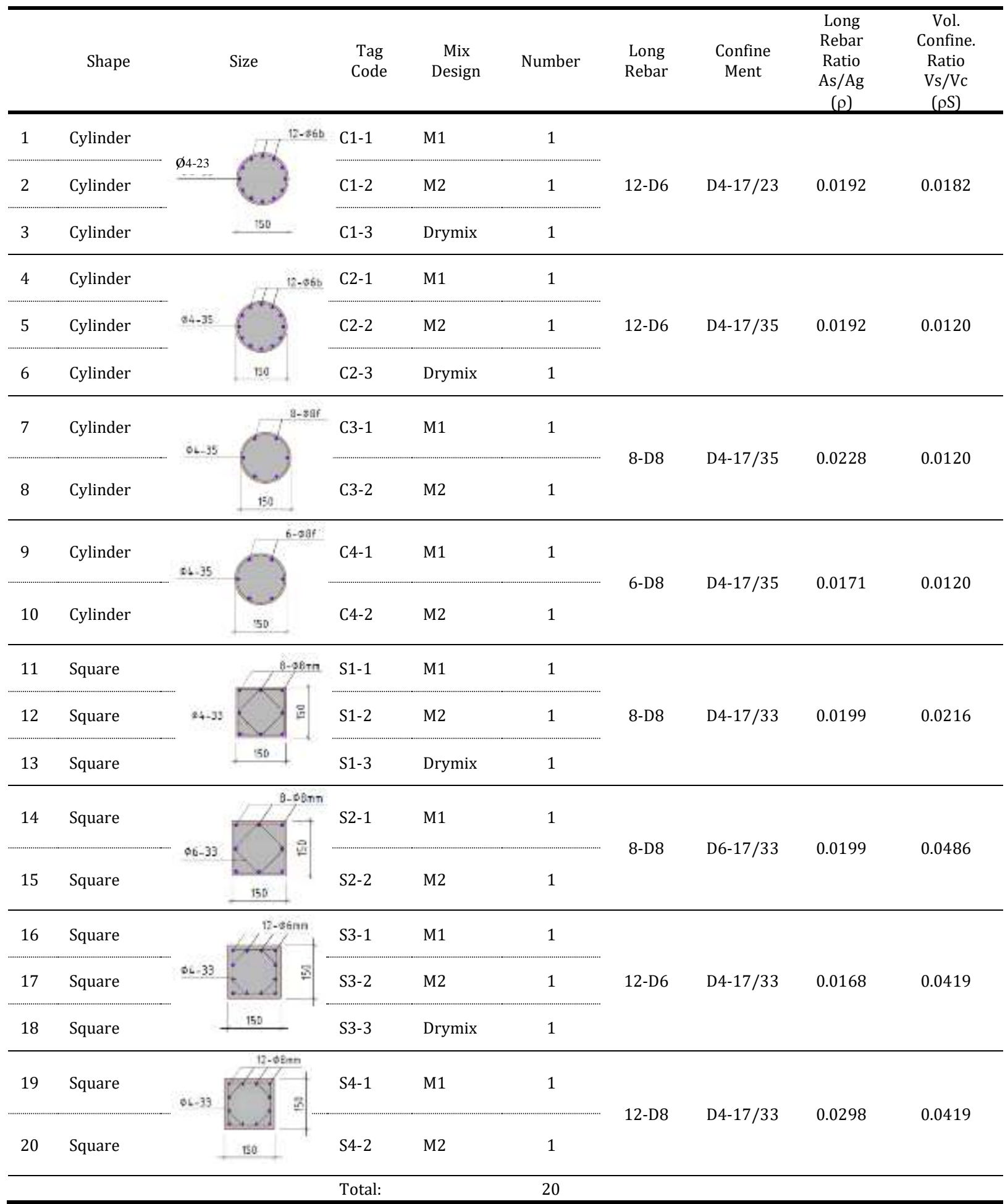

\subsection{Proposed Coefficients}

A general expression to express the triaxial strength of concrete in terms of uniaxial strength and lateral confinement pressure can be written as:

$$
\begin{gathered}
f_{c c}^{\prime}=f^{\prime}{ }_{c o}+k_{1} f_{i} \\
k_{1}=6.7\left(f_{i}\right)^{-0.17} \\
k_{2}=0.26 \sqrt{\left(\frac{b_{c}}{s}\right)} \cdot\left(\frac{b_{b}}{s 1}\right) \cdot\left(\frac{1}{f_{i}}\right) \leq 1.0
\end{gathered}
$$


where $f^{\prime}{ }_{c c}$ is the confined strength of concrete, $f_{c o}^{\prime}$ is the unconfined strength of concrete, $k_{1}$ is the coefficient of confinement, and $f_{i}$ is the uniform lateral pressure of confinement bar (MPa).

Table 5 Acquired data from the experiment

\begin{tabular}{|c|c|c|c|c|c|c|c|c|c|c|c|}
\hline NO & TAG CODE & MIX & $\begin{array}{c}\text { LONG } \\
\text { REBAR } \\
\end{array}$ & $\begin{array}{c}\text { CONFINE } \\
\text { MENT }\end{array}$ & NUMBER & $\begin{array}{c}\text { P MAX } \\
\text { CALCULATION } \\
\text { (AS COLUMN) } \\
\text { kN } \\
\end{array}$ & $\begin{array}{r}\text { P MAX TEST } \\
\text { (JTM-2000) } \\
(\mathrm{kN}) \\
\end{array}$ & $\begin{array}{c}\text { DISPLACEMENT } \\
\text { AT MAX. FORCE } \\
(\mathrm{mm})\end{array}$ & $\begin{array}{c}\text { DISPLACEMENT } \\
\text { AT BREAK } \\
(\mathrm{mm})\end{array}$ & $\begin{array}{c}\text { STRAIN AT MAX } \\
\text { PRESSURE } \\
\text { (JTM2000) }\end{array}$ & $\begin{array}{l}\text { STRAIN AT } \\
\text { BREAK } \\
\text { (JTM2000) }\end{array}$ \\
\hline 1 & C1-1 & M1 & \multirow{3}{*}{ 12-D6 } & \multirow{3}{*}{ D4-17/23 } & 1 & 415.92 & 383.13 & 10.13 & 16.34 & 0.02026 & 0.03268 \\
\hline 2 & $\mathrm{C} 1-2$ & M2 & & & 1 & 448.09 & 549.80 & 8.50 & 13.92 & 0.01700 & 0.02784 \\
\hline 3 & $\mathrm{C} 1-3$ & Drymix & & & 1 & 453.72 & 552.18 & 13.62 & 15.26 & 0.02724 & 0.03052 \\
\hline 4 & $\mathrm{C} 2-1$ & M1 & \multirow{3}{*}{ 12-D6 } & \multirow{3}{*}{ D4-17/35 } & 1 & 415.92 & 300.73 & 5.35 & 10.72 & 0.01070 & 0.02144 \\
\hline 5 & $\mathrm{C} 2-2$ & M2 & & & 1 & 448.09 & 436.71 & 9.02 & 14.10 & 0.01805 & 0.02820 \\
\hline 6 & $\mathrm{C} 2-3$ & Drymix & & & 1 & 453.72 & 572.21 & 8.97 & 10.52 & 0.01794 & 0.02104 \\
\hline 7 & C3-1 & M1 & \multirow{2}{*}{ 8-D8 } & \multirow{2}{*}{ D4-17/35 } & 1 & 422.65 & 400.86 & 10.25 & 13.84 & 0.02050 & 0.02769 \\
\hline 8 & C3-2 & $\mathrm{M} 2$ & & & 1 & 454.70 & 500.76 & 10.27 & 16.63 & 0.02054 & 0.03326 \\
\hline 9 & C4-1 & M1 & \multirow{2}{*}{ 6-D8 } & \multirow{2}{*}{ D4-17/35 } & 1 & 374.70 & 419.18 & 8.63 & 13.40 & 0.01726 & 0.02681 \\
\hline 10 & C4-2 & M2 & & & 1 & 406.94 & 400.47 & 11.15 & 17.79 & 0.02230 & 0.03558 \\
\hline 11 & S1-1 & M1 & \multirow{3}{*}{ 8-D8 } & \multirow{3}{*}{ D4-17/33 } & 1 & 485.73 & 595.50 & 7.12 & 12.42 & 0.01781 & 0.02485 \\
\hline 12 & $\mathrm{~S} 1-2$ & $\mathrm{M} 2$ & & & 1 & 526.74 & 601.22 & 10.26 & 23.73 & 0.02564 & 0.04746 \\
\hline 13 & S1-3 & Drymix & & & 1 & 533.92 & \multicolumn{3}{|r|}{ FAILED DURING TES } & 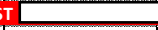 & \\
\hline 14 & S2-1 & M1 & \multirow{2}{*}{ 8-D8 } & \multirow{2}{*}{ D6-17/33 } & 1 & 485.73 & 390.11 & 12.99 & 49.00 & 0.03248 & 0.09800 \\
\hline 15 & $\mathrm{S2}-2$ & $\mathrm{M} 2$ & & & 1 & 526.74 & 599.20 & 7.95 & 33.85 & 0.01988 & 0.06769 \\
\hline 16 & S3-1 & M1 & \multirow{3}{*}{ 12-D6 } & \multirow{3}{*}{ D4-17/33 } & 1 & 479.00 & 579.72 & 7.60 & 10.32 & 0.01900 & 0.02065 \\
\hline 17 & $\mathrm{S3}-2$ & $\mathrm{M} 2$ & & & 1 & 520.13 & 512.40 & 9.19 & 12.69 & 0.02298 & 0.02538 \\
\hline 18 & $53-3$ & Drymix & & & 1 & 527.33 & 903.76 & 8.56 & 10.23 & 0.02140 & 0.02046 \\
\hline 19 & S4-1 & M1 & \multirow{2}{*}{$12-\mathrm{D} 8$} & \multirow{2}{*}{ D4-17/33 } & 1 & 581.62 & 632.09 & 9.31 & 13.51 & 0.02328 & 0.02702 \\
\hline 20 & S4-2 & M2 & & & 1 & 622.26 & 626.30 & 9.35 & 14.56 & 0.02338 & 0.02912 \\
\hline 21 & C5-1-1 & M1 & \multirow{12}{*}{\multicolumn{2}{|c|}{$\begin{array}{c}\mathrm{N} / \mathrm{A} \\
(\mathrm{PLAIN})\end{array}$}} & 1 & 230.86 & 209.43 & 9.35 & 10.49 & 0.01870 & 0.02097 \\
\hline 22 & C5-1-2 & M1 & & & 1 & 230.86 & 193.67 & 7.02 & 9.06 & 0.01404 & 0.01812 \\
\hline 23 & C5-2-1 & M2 & & & 1 & 263.66 & 272.15 & 5.39 & 6.16 & 0.01078 & 0.01232 \\
\hline 24 & C5-2-2 & M2 & & & 1 & 263.66 & 236.13 & 7.03 & 8.29 & 0.01406 & 0.01658 \\
\hline 25 & C5-3-1 & Drymix & & & 1 & 269.40 & 487.11 & 6.37 & 6.44 & 0.01594 & 0.01611 \\
\hline 26 & C5-3-2 & Drymix & & & 1 & 269.40 & 363.88 & 5.60 & 5.66 & 0.01400 & 0.01416 \\
\hline 27 & S5-1-1 & M1 & & & 1 & 293.94 & 263.57 & 6.51 & 7.33 & 0.01628 & 0.01834 \\
\hline 28 & S5-1-2 & M1 & & & 1 & 293.94 & 275.62 & 6.34 & 7.29 & 0.01585 & 0.01823 \\
\hline 29 & S5-2-1 & M2 & & & 1 & 335.70 & 293.30 & 6.18 & 7.00 & 0.01545 & 0.01750 \\
\hline 30 & $55-2-2$ & M2 & & & 1 & 335.70 & 256.03 & 7.81 & 8.93 & 0.01954 & 0.02232 \\
\hline 31 & S5-3-1 & Drymix & & & 1 & 343.01 & 441.30 & 5.27 & 5.30 & 0.01317 & 0.01325 \\
\hline 32 & $55-3-2$ & Drymix & & & 1 & 343.01 & 421.99 & 6.85 & 6.85 & 0.01713 & 0.01713 \\
\hline
\end{tabular}
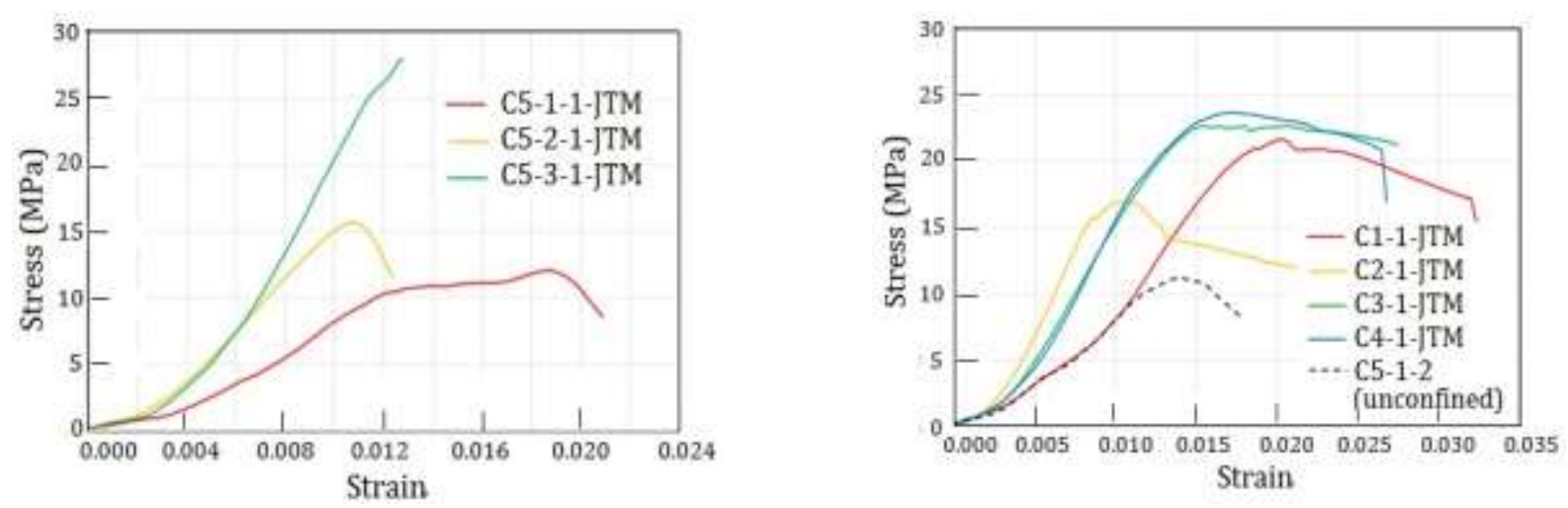

Figure 6 Stress-strain curves from unconfined Figure 7 Stress-strain curves from cylinder cylinder specimens, concrete grades M1, M2, and M3 (drymix) specimens, concrete grade M1 with various confinement bars (Results from the JTM-2000) 


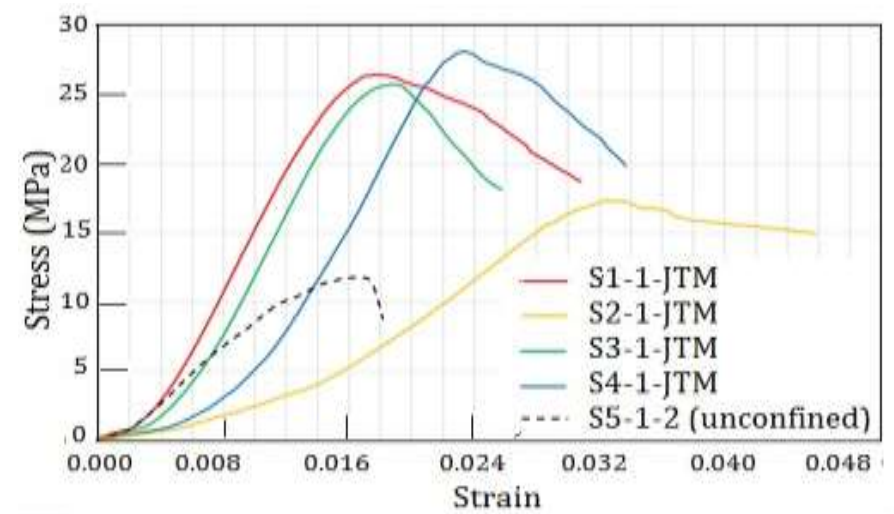

Figure 8 Stress-strain curves from square specimens, concrete grade M1 with various confinement bars (Results from the JTM-2000)

Input each value of $f^{\prime} c 0$ and $f_{c c}^{\prime}$ from the experiment.

$$
f_{c c . E x p .}^{\prime}=f_{c o . E x p}^{\prime}+\left[6.7\left(f i^{n}\right)\right] \cdot f_{i}
$$

We then seek the new value of power "n."

$$
\begin{aligned}
& \frac{f_{c c ; E x p . .}^{\prime}-f_{c 0 ; E x p .}^{\prime}}{6.7}=\left(f_{i}\right)^{n} . f_{i} \\
& \frac{f_{c c ; E x p . .}^{\prime}-f^{\prime}{ }_{c 0 ; E x p .}}{6.7}=\left(f_{i}\right)^{n+1} \\
& n=\left[\log _{f_{i}} \frac{f_{c c ; E x p}-f^{\prime}{ }_{c 0 ; E x p} .}{6.7}\right]-1
\end{aligned}
$$

The new power " $n$ " obtained is -0.63148 and is proposed to replace the power " $n$ " of Saatcioglu-Razvi of $-0,17$. The proposed new $k_{1}$ formula for a cylindrical section under compression is:

$$
\begin{gathered}
k_{1 ; \text { Prop. }}=6.7\left(f_{i}\right)^{-0.63148} \\
f_{\text {cc.Prop. }}^{\prime}=f_{\text {co.Exp }}^{\prime}+\left[6.7\left(f i^{n-0.63148}\right)\right] . f_{i}
\end{gathered}
$$

From the experiment, the fcc' value is to be checked with the $k 1$ value from the analysis

\begin{tabular}{|c|c|c|c|c|c|c|c|c|c|}
\hline $\begin{array}{c}\text { Tag } \\
\text { Code }\end{array}$ & Shape & $\begin{array}{c}\mathrm{Fi} \\
(\mathrm{MPa})\end{array}$ & $\begin{array}{c}\text { f'co } \\
\text { experiment } \\
(\mathrm{MPa})\end{array}$ & $\begin{array}{c}\mathrm{f}^{\prime c c} \\
\text { experiment } \\
(\mathrm{MPa})\end{array}$ & $\begin{array}{c}\mathrm{k} 1 \\
\text { proposed }\end{array}$ & $\begin{array}{c}\mathrm{f}^{\prime c c} \\
\text { proposed }\end{array}$ & $\begin{array}{c}\text { Ratio f'cc } \\
\text { Prop/exp } \\
\text { n2 }\end{array}$ & $\begin{array}{c}\text { Proposed } \\
\text { power n2 } \\
\text { (mean value) }\end{array}$ & $\begin{array}{l}\text { Proposed } \\
\text { power } n 1\end{array}$ \\
\hline C1-1 & Cylinder & 3.57 & 11.581 & 21.678 & 2.99992 & 22.28944 & 1.02821 & -0.63148 & -0.6777 \\
\hline C1-2 & Cylinder & 3.57 & 14.517 & 31.111 & 2.99992 & 25.22544 & 0.81082 & -0.63148 & -0.2873 \\
\hline $\mathrm{C} 1-3$ & Cylinder & 3.57 & 24.352 & 31.236 & 2.99992 & 35.06044 & 1.12244 & -0.63148 & -0.9787 \\
\hline $\mathrm{C} 2-1$ & Cylinder & 2.35 & 11.581 & 16.194 & 3.91069 & 20.75439 & 1.28161 & -0.63148 & -1.4378 \\
\hline $\mathrm{C} 2-2$ & Cylinder & 2.35 & 14.517 & 24.701 & 3.91069 & 23.69039 & 0.95909 & -0.63148 & -0.5089 \\
\hline $\mathrm{C} 2-3$ & Cylinder & 2.35 & 24.352 & 32.380 & 3.91069 & 33.52539 & 1.03537 & -0.63148 & -0.7879 \\
\hline C3-1 & Cylinder & 2.35 & 11.581 & 22.676 & 3.91069 & 20.75439 & 0.91526 & -0.63148 & -0.4084 \\
\hline C3-2 & Cylinder & 2.35 & 14.517 & 28.333 & 3.91069 & 23.69039 & 0.83614 & -0.63148 & -0.1512 \\
\hline C4-1 & Cylinder & 2.35 & 11.581 & 23.692 & 3.91069 & 20.75439 & 0.87601 & -0.63148 & -0.3056 \\
\hline \multirow[t]{2}{*}{ C4-2 } & Cylinder & 2.35 & 14.517 & 22.659 & 3.91069 & 23.69039 & 1.04552 & -0.63148 & -0.7714 \\
\hline & & & & & & Average: & 0.99105 & Mean: $\sum n 1 / 10$ & -0.63148 \\
\hline
\end{tabular}
(using the Saatcioglu-Razvi formula). The results of the analysis show that 2 specimens deviated from the expected range of $f_{c c}^{\prime}$. By neglecting those 2 deviated results, the ratio of $f_{\text {cc.Experiment }}^{\prime}$ and $f_{c c \text {.Analysis }}^{\prime}$ is approximately 1.15 (or approximately a $15 \%$ accuracy margin), as presented in Table 7. The proposed new $k_{1}$ value is presented in Table 6.

Table 6 Proposed new k1 value for cylindrical section under compression 
Based on the experimental test results for 16 square specimens, the new relationship between $\mathrm{f}_{\mathrm{c} 0}$ and $\mathrm{f}_{\mathrm{cc}}$ for square specimens was developed by modifying the $k_{1}$ coefficient.

Table 7 Cylinder specimen f'cc prediction from analysis using the Saatcioglu-Razvi formula

\begin{tabular}{|c|c|c|c|c|c|c|c|c|}
\hline $\begin{array}{l}\text { Tag } \\
\text { Code }\end{array}$ & Shape & $\begin{array}{c}\mathrm{Fi} \\
(\mathrm{MPa})\end{array}$ & $\begin{array}{c}\mathrm{f}^{\prime} \mathrm{co} \\
\text { experiment } \\
(\mathrm{MPa})\end{array}$ & $\begin{array}{c}\mathrm{f}^{\prime} \mathrm{cc} \\
\text { experiment } \\
(\mathrm{MPa})\end{array}$ & $\begin{array}{c}\mathrm{f}^{\prime c c} \\
\text { analysis } \\
(\mathrm{MPa})\end{array}$ & $\begin{array}{c}\mathrm{k} 1 \\
\text { analysis }\end{array}$ & $\begin{array}{c}\mathrm{k} 2 \\
\text { analysis }\end{array}$ & $\begin{array}{c}\text { Ratio f'cc } \\
\text { Analysis/experiment }\end{array}$ \\
\hline C1-1 & Cylinder & 3.57 & 11.581 & 21.678 & 30.84501 & 5.39672 & 0.92469 & 1.42287 \\
\hline C1-2 & Cylinder & 3.57 & 14.517 & 31.111 & 33.78101 & 5.39672 & 0.92469 & 1.08582 \\
\hline C1-3 & Cylinder & 3.57 & 24.352 & 31.236 & 43.61601 & 5.39672 & 0.92469 & 1.39634 \\
\hline $\mathrm{C} 2-1$ & Cylinder & 2.35 & 11.581 & 16.194 & 25.17679 & 5.79599 & 0.92469 & 1.55470 \\
\hline $\mathrm{C} 2-2$ & Cylinder & 2.35 & 14.517 & 24.701 & 28.11279 & 5.79599 & 0.92469 & 1.13812 \\
\hline $\mathrm{C} 2-3$ & Cylinder & 2.35 & 24.352 & 32.380 & 37.94779 & 5.79599 & 0.92469 & 1.17195 \\
\hline C3-1 & Cylinder & 2.35 & 11.581 & 22.676 & 25.17679 & 5.79599 & 0.75501 & 1.11028 \\
\hline C3-2 & Cylinder & 2.35 & 14.517 & 28.333 & 28.11279 & 5.79599 & 0.75501 & 0.99223 \\
\hline C4-1 & Cylinder & 2.35 & 11.581 & 23.692 & 25.17679 & 5.79599 & 0.65385 & 1.06267 \\
\hline $\mathrm{C} 4-2$ & Cylinder & 2.35 & 14.517 & 22.659 & 28.11279 & 5.79599 & 0.65385 & 1.24069 \\
\hline \multicolumn{8}{|c|}{ Average from 8 specimens: } & 1.14976 \\
\hline
\end{tabular}

The general equation for $k_{1}$ from the Saatcioglu-Razvi equation was adapted by seeking a new value for power $-0,17$. For a confined square section under compression, the new power "n" obtained is -0.5744 and is proposed to replace the power " $n$ " of Saatcioglu-Razvi of -0.17 . The proposed new $k_{1}$ formula is as below:

$$
\begin{gathered}
k_{1 ; \text { Prop. }}=6.7\left(f_{l e}\right)^{-0.5744} \\
f_{\text {c.Prop. }}^{\prime}=f_{\text {co.Exp }}^{\prime}+\left[6.7\left(f_{l e}^{-0.5744}\right)\right] . f_{l e}
\end{gathered}
$$

The accuracy of this new power " $\mathrm{n}$ " satisfies the ratio of $f_{\text {cc.Proposed }}^{\prime}$ and $f_{\text {'cc.Experiment, }}$ which is 0.958 . The prediction of the post-peak stress-strain trajectory in this model is calculated based on the regression analysis of test data by Saatcioglu and Razvi (1992). The following expression was used to establish the strain at a certain stress value beyond the peak by inputting $f_{c c}^{\prime}$ and $\varepsilon_{1}$ from the experiment.

$$
f_{c}=f_{C C}^{\prime}\left[2\left(\frac{\varepsilon_{c}}{\varepsilon_{1}}\right)-\left(\frac{\varepsilon_{c}}{\varepsilon_{1}}\right)^{2}\right]^{1 /(1+2 K)} \leq f_{C C}^{\prime}
$$

where $f^{\prime}{ }_{c c}$ is the maximum stress of confined section, $\varepsilon_{c}$ is the strain of confined section at working stress f'c, and $\varepsilon_{1}$ is the strain of confined section at maximum stress.

Figures 9 and 10 show a fairly close fit between the proposed models obtained previously for the confined cylinder and square concrete specimens and the corresponding experiment results.
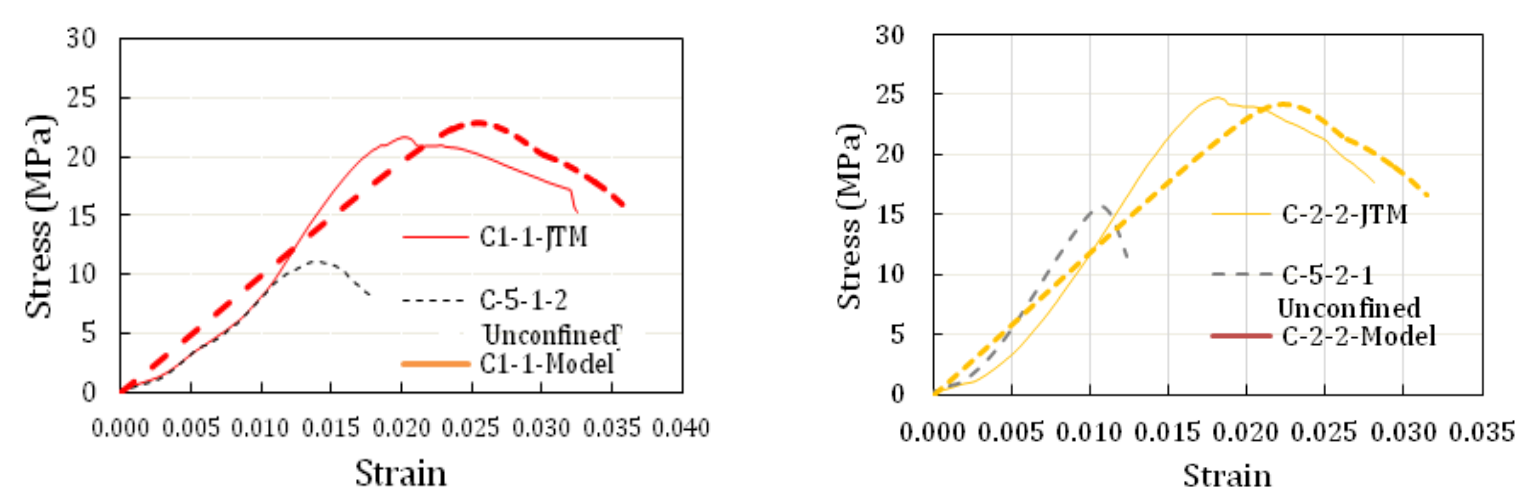

Figure 9 Comparison between stress-strain from confined cylinder experimental specimens and the proposed model ( $\mathrm{C}-1-1$ and $\mathrm{C}-2-2$ specimens) 

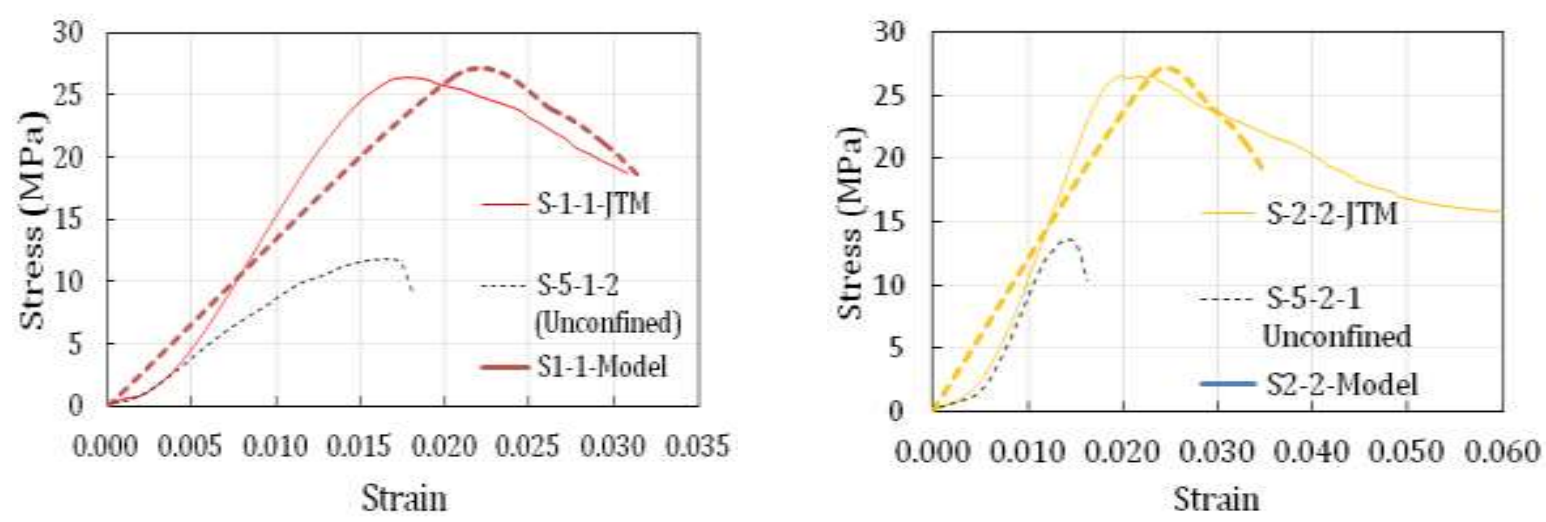

Figure 10 Comparison between stress-strain from confined square experimental specimens and the proposed model (S-1-1 and S-2-2 specimens)

The peak stress obtained by the proposed model occurs at a larger strain, and the proposed stress-strain curve before the peak is nearly linear, whereas the initial condition of the latter condition could compensate for the higher experimental stress at the same strain before the peak stress. The proposed model for confined concrete using sand coated polypropylene coarse aggregate was derived from compression tests on cylindrical and square column specimens. We do not yet know whether the model will fit to confined concrete stressstrain curves derived from compression tests applied to rectangular concrete column specimens made with the same polypropylene coarse aggregate. Another important remark is that the average ratio of the confined to unconfined stress, as shown in Figure 9 and Figure 10, is approximately 2 , which is higher than that of normal concrete.

\section{Conclusions}

The proposed procedure presented here provides satisfactory results for establishing a stress-strain relationship for confined lightweight concrete and is sufficient to cover the gap between experimental and analytical results. The reduced scale used in the experiment for cylindrical and square lightweight concrete specimens, which are one-third of the original dimensions, has provided satisfactory coefficients of confinement. In the future, full-scale experiments or reduced-scale rectangular column specimen experiments are required to validate the results obtained in this study using reduced-scale specimens.

\section{Acknowledgements}

The authors express their gratitude to the Ministry of Education, Culture, Research and Technology, Republic Indonesia and Universitas Indonesia for facilitating this study with Prime Basic Research Grant 2020-2021, No. NKB-198/UN2.RST/HKP.05.00/2021.

\section{References}

Afsari, D., 2017. Studi Karakteristik Beton Ringan Dengan Agregat Polypropylene Terhadap Kuat Tekan Kubus Dan Lentur Beton Ringan (Study of the Lightweight Concrete Characteristics with Polypropylene Aggregate Against Cube Compressive Strength and Flexibility of Lightweight Concrete). Final Project, Universitas Indonesia

Al Bakri, A.M.M., Tamizi, S.M., Rafiza, A.R., Zarina, Y., 2011. Investigation of HDPE Plastic Waste Aggregate on the Properties of Concrete. Journal of Asian Scientific Research, Volume 1(7), pp. 340-345

Chang, W, Zheng, W, Hao, M., 2020. Lateral Response of Ultra-High Performance Concrete Columns Confined with High-Strength Spiral Stirrups. Structural Concrete, Volume 
21(12), pp. 2408-2419

Choi, Y.W., Moon D.J., Kim Y.J., Lachemi M., 2009. Characteristics of Mortar and Concrete Containing Fine Aggregate Manufactured from Recycled Waste Polyethylene Terephthalate Bottles. Construction and Building Materials, Volume 23(8), pp. 28292835

Frigione, M., 2010. Recycling of PET Bottles as Fine Aggregate in Concrete. Waste Management, Volume 30(6), pp. 1101-1106

Islam, M.J., Meherier, M.S., Islam, A.K.M.R., 2016. Effects of Waste PET as Coarse Aggregate on the Fresh and Harden Properties of Concrete. Construction and Building Materials, Volume 125, pp. 946-951

Jawaid, M., Khan, M.M., 2018. Polymer-based Nanocomposites for Energy and Environmental Applications, Cambridge, UK: Woodhead Publishing

Kent, D.C., Park, R., 1971. Flexural Members with Confined Concrete. ASCE Proceedings, Volume 97 (ST7), pp. 1969-1990

Kurdi, O., Rahman, R.A., 2010. Finite Element Analysis of Road Roughness Effect to Stress Distribution of Heavy Duty Truck Chassis. International Journal of Technology, Volume $1(1)$, pp 57-64

Li, J., Deng, Z, Yao, J., 2020. Research on Uniaxial Compressive Behavior of High-Strength Spiral Stirrups Confined Circular Ultra-High Performance Concrete Columns. Structural Concrete. Volume 21(6), pp. 1-17

Maddah H.A., 2016. Polypropylene as a Promising Plastic: A Review. American Journal of Polymer Science, Volume 6(1), pp 1-11

Mander, J.B., Priestley, M.J.N., Park, R., 1988. Observed Stress-Strain Behavior of Confined Concrete. Journal of Structural Engineering, Volume 114(8), pp. 1827-1849

Neville, A.M., 2011. Properties of Concrete, $5^{\text {th }}$ edition., London: Pearson

Pamudji, G., Heribowo, B., Prayoga, A.Y., Purnomo, H., 2018. Bond-slip Behavior of Steel Bar Embedded in Lightweight Concrete using Polypropylene Coarse Aggregate Coated with Sand. Materials Science Forum, Volume 929, pp. 102-108

Purnomo, H., Pamudji, G., Satim, M., 2017a. Influence of Uncoated and Coated Plastic Waste Coarse Aggregates to Concrete Compressive Strength. Matec Web of Conference, Volume 101, pp. 1-5

Purnomo, H., Nursani, R., Mentari, S., Rahim, S.A., Tjahjono, E., 2017b. Numerical Evaluation of the Shear Behavior of a Metal Shear Key Used in Joining Precast Concrete Segmental Bridge Girders without Epoxy. International Journal of Technology, Volume 8(6), pp. 1050-1059

Purnowidodo, A., Anam, K., Darmadi, D.B., Wahyudi, A., 2018. The Effect of Fiber Orientation and Stress Ratio on the Crack Growth Behaviour of Fiber Metal Laminates (FMLs). International Journal of Technology, Volume 9(5), pp. 1039-1048

Saatcioglu, M., Razvi, S.R., 1992. Strength and Ductility of Confined Concrete. Journal of Structural Engineering, Volume 118(6), pp. 1590-1607

Scott, B.D., 1980. Stress Strain Relationships for Confined Concrete Rectangular Sections. Master's Thesis, Graduate Program, University of Canterbury, New Zealand

Scott, B.D., Park, R., Priestley, M.J.N., 1982. Stress-Strain Behavior of Concrete Confined by Overlapping Hoops at Low and High Strain Rates. American Concrete Institute Journal Proceedings, Volume 79(1), pp 13-27

Standar Nasional Indonesia, 2002. SNI 03-2847-2002. Tata Cara Perhitungan Struktur Beton Untuk Bangunan Gedung (Procedure for Calculation of Concrete Structures for Buildings). 